\title{
Summer temperature and all-cause mortality from 2006 to 2015 for Hyderabad, India
}

\author{
Suresh K Rathi ${ }^{1}$, Prahlad R Sodani ${ }^{2}$
}

1. IIHMR University, Jaipur \& MAMTA Health Institute for Mother and Child, New Delhi - 110048.

Email: rathisj07@gmail.com

2. President, IIHMR University 1, Prabhu Dayal Marg,Near Sanganer Airport, Jaipur - 302029. Email: sodani@ iihmr.edu.in

\begin{abstract}
:
Background: Studies have documented a significant association between temperature and all-cause mortality for various cities but such data are unavailable for Hyderabad City.

Objective: The objective of this work was to assess the association between the extreme heat and all-cause mortality for summer months (March to June) from 2006 to 2015 for Hyderabad city population.

Methods: We obtained the data on temperature and all-cause mortality for at least ten years for summer months. Descriptive and Bivariate analysis were conducted. Pearson correlation coefficient was used to study the relationship between heat and all-cause mortality for lag time effect.

Results: A total of 122,117 deaths for 1,220 summer days (2006 to 2015) were analyzed with mean daily all-cause mortality was $100.1 \pm 21.5$. There is an increase of $16 \%$ and $17 \%$ per day mean all-cause mortality at the maximum temperature of $\geq 40^{\circ} \mathrm{C}$ and for extreme danger days (Heat Index $>54^{\circ} \mathrm{C}$ ) respectively. The mean daily all-cause mortality shows a significant association with maximum temperature $(\mathrm{P}<0.001)$ and Heat Index from caution to extreme danger risk days $(\mathrm{P}<0.0183)$. The lag effect of extreme heat on all-cause mortality for the study period (2006 to 2015) was at peak on same day of the maximum temperature $(\mathrm{r}=0.273$ at $\mathrm{p}<0.01)$.

Conclusion: The study concludes that the impact of ambient heat in the rise of all-cause mortality is clearly evident $(16 \%$ mean deaths/day). There was no lag effect from the effect of extreme heat on all-cause mortality as the peak period was the same as the maximum temperature. Hence heat action plans are needed. However, extreme heat-related mortality merits further analysis.
\end{abstract}

Keywords: Heat wave; all-cause mortality; urban; humidity; heat index; India.

DOI: https://dx.doi.org/10.4314/ahs.v21i3.59

Cite as: Rathi SK, Sodani PR. Summer temperature and all-cause mortality from 2006 to 2015 for Hyderabad, India. Afri Health Sci. 2021;21(3). 1474-1481. bttps://dx.doi.org/10.4314/abs.v21i3.59

\section{Introduction}

Global warming and the El Nino events in 2015 and 2016 resulted in high temperatures across the planet ${ }^{1,2}$. The WHO estimates that between 2030 and 2050 global climate change is predicted to cause a further 250,000 deaths per annum mainly associated with malaria, malnutrition, diarrhoea and heat stress ${ }^{3}$. Rising temperature is nearly the universal phenomena and scientists are researching and reporting its impact on health, development and productivity. Chronic exposure to extend

\section{Corresponding author: \\ Suresh K Rathi \\ A-18, Elegance Apple, near Gunatit Residency, \\ Behind Collaberra, Gotri-Sevasi Road, Vadodara - 390021 - Gujarat, India \\ Email: rathisj07@gmail.com}

or changes in heat and humidity (including and beyond episodic heatwaves) results in impacts on behavioural, physical and psychological state and mortality ${ }^{4}$. Impact is often amplified in urban areas and may cause impacts on labour and overall productivity, with associated economic aftermath as urban areas may face higher levels of temperature than adjacent suburb and rural areas due to the Urban Heat Island (UHI) effect ${ }^{5}$. The mortality impact of high heat has been explored for several regions of the planet ${ }^{6,7,8}$. India also witnessed a series of heat waves with considerable mortality ${ }^{9,10,11}$. The destructive impact of one wave in India in May 2015, with over 2200 fatalities, demonstrated that extreme heat may be a serious issue even in countries regularly exposed to high temperatures ${ }^{12}$. Heatwaves are expected to increase further not only in intensity, but also in duration and frequency ${ }^{11,13,14}$.

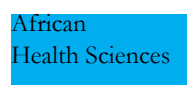

(C) 2021 Rathi SK et al. Licensee African Health Sciences. This is an Open Access article distributed under the terms of the Creative commons Attribution License (https://creativecommons.org/licenses/BY/4.0), which permits unrestricted use, distribution, and reproduction in any medium, provided the original work is properly cited. 
Generally, the linkages between heat and all-cause mortality are studied at broader scales which are less likely relevant at local (city) level. Coastal, desert and dry cities could also be different from global climate change perspective and its mitigation measures. Therefore, generation of local evidence during this domain is critical to first understand the character and magnitude of health effects, then to develop and implement plans for risk mitigation.

To the authors knowledge there have been no studies in the Hyderabad area with Telangana reporting high number of heat stroke cases and deaths due to heat waves ${ }^{15,16}$. Hyderabad is a very urbanized city in Telangana with high heat wave risk according to news reports. Hyderabad has been selected for robust but scientific evidence generation which may be helpful in the planning of heat wave mitigation efforts. The aim of this paper is to estimate the impact of heat wave on mortality in Hyderabad. It is important to review the cumulative deaths at the town level. The target of the study is to characterize the acute heat (daily maximum temperature, daily minimum temperature, daily mean temperature, and Heat index (HI) impacts on all-cause mortality for summer months (March to June) from 2006 to 2015 for urban population of Hyderabad.

\section{Methods}

\section{Study Area}

Hyderabad is Telangana's capital and largest Indian state city, covering 650 square kilometers along Musi River banks. Hyderabad's population is 6.8 million (2011 Census) with a population density of 10,477 people per square kilometer making it the fourth-populated Indian city. Hyderabad has a dry and humid tropical climate bordering on a hot semi-arid climate. The mean annual temperature is $26.6^{\circ} \mathrm{C}$; average monthly temperatures range from $21-33^{\circ} \mathrm{C}$. Summers (March - June) are hot and humid, with mean highs in the mid-to-high 30s Celsius; between April and June, maximum temperatures often exceed $40^{\circ} \mathrm{C}$. May is the hottest month, as temperatures range from $26^{\circ} \mathrm{C}$ to $39^{\circ} \mathrm{C}$ each day. Between June and September, heavy rain from the southwest summer monsoon comes providing Hyderabad with much of its mean annual rainfall.

\section{Study Design}

Retrospective cross sectional analysis of all-cause mortality data with temperature, humidity and heat index for Hyderabad city.

\section{Data Collection}

i) Climatic data (Temperature and Humidity Data)

The data (secondary) on Temperature and Humidity were collected through online from Tutiempo Network, S.L http://www.tutiempo.net/en/Climate/.html ${ }^{17}$ for the summer months for the years of 2006 to 2015 . The values were collected for daily average, maximum and minimum temperature $\left({ }^{\circ} \mathrm{C}\right)$ and daily average relative humidity (\%) for Hyderabad City. Daily maximum temperature and relative humidity data were used in the calculation of the HI.

Summer Day: It is defined as any day from March to June.

Heat Index: HI (feel like temperature) is a measure to estimate how hot it really feels when relative humidity is factored with the actual air temperature. Rothfusz equation ${ }^{18}$ for $\mathrm{HI}$ calculation is applied as it is widely in practice for cities $5,11,19,20$.

Heat Index equation:

Where, $\mathrm{T}=$ ambient dry bulb temperature $\left({ }^{\circ} \mathrm{C}\right)$ and $\mathrm{R}=$ relative humidity $(\%)$.

The HI was further classified into Extreme Danger: $>54^{\circ} \mathrm{C}$; Danger: $41^{\circ} \mathrm{C}-54^{\circ} \mathrm{C}$; Extreme Caution: $32^{\circ} \mathrm{C}-$ $41^{\circ} \mathrm{C}$ and Caution: $27^{\circ} \mathrm{C}-32^{\circ} \mathrm{C}^{11}$.

\section{ii) Mortality Data}

The mortality data (secondary) of the Hyderabad city were obtained from the Birth and Death Registration Department of the Municipal Corporation / Municipality for the years from 2006 to 2015 through website (http://www.ghmc.gov.in/deaths/deathssearch. asp?id $=1 \&$ circlepd $=\&$ circle $=1 \&$ ward $=\&$ date $1=01-\mathrm{Ja}$ n-2016\&date2 $=14$-Jun-2016\&dname $=\& d s e x=$ A\&offset $=90)$.

\section{Ethical Clearance}

The study has utilized existing (secondary) data, and therefore, no direct interaction was made with human beings. The data do not have any identifying information (anonymous in analysis). However, ethical clearance has been taken from the Institutional Committee for Ethics and Review of Research of IIHMR University.

\section{Statistical Analysis}

Data were processed in Microsoft Excel and analyzed through Stata (14.2) and SPSS (20.0). Descriptive, and bivariate analysis were conducted. Numerical data were expressed as the means and standard deviation (means \pm s.d.). The student's t-test and ANOVA were used to examine differences in the means of variables (average temperature, maximum temperature, and heat index). ANOVA was used for testing the significance of differences between the mean all-cause mortality (death) 
values at maximum temperature of $<35^{\circ} \mathrm{C}, 35-39^{\circ} \mathrm{C}$ and $\geq 40^{\circ} \mathrm{C}$ and heat index of $27-32^{\circ} \mathrm{C}, 32-41^{\circ} \mathrm{C}, 41-54^{\circ} \mathrm{C}$ and $>54^{\circ} \mathrm{C}$. Pearson correlation analysis was used to determine the relationship for the maximum temperature, average temperature, minimum temperature, relative humidity and heat index with all-cause mortality for lag time effect. The probability (p) level of $\leq 0.05$ was considered significant.

\section{Results}

A total of 122,117 deaths (all-cause mortality) for 1,220 summer days (2006-2015) were analyzed with temperature and relative humidity.
Table-1 shows that mean maximum temperature, mean relative humidity and mean heat index during summer were $37.8 \pm 3.5^{\circ} \mathrm{C}, 41.1 \pm 14.7 \%$ and $43.3 \pm 5.3^{\circ} \mathrm{C}$ respectively for the study period. The yearly mean maximum temperature during summer ranges from $36.2 \pm$ $3.4^{\circ} \mathrm{C}$ for the year 2006 to $38.8 \pm 3.2^{\circ} \mathrm{C}$ in 2010 . The highest recorded value for maximum temperature, relative humidity and heat index during summer were $46.0^{\circ} \mathrm{C}, 95 \%$ and $68.9^{\circ} \mathrm{C}$ respectively for the study period. The yearly mean $\mathrm{HI}$ is lowest in $2009\left(41.7 \pm 4.1^{\circ} \mathrm{C}\right)$ and highest in $2012\left(44.7 \pm 5.5^{\circ} \mathrm{C}\right)$.

Table 1. Year-wise statistics of mean and range of maximum temperature, average relative humidity, heat index (HI) and days with maximum temperature $\geq 40^{\circ} \mathrm{C}$ for the years 2006 to 2015, Hyderabad

\begin{tabular}{|c|c|c|c|c|c|c|}
\hline Year & $\begin{array}{c}\text { Maximum } \\
\text { Temperature }{ }^{\circ} \mathrm{C} \\
(\text { mean } \pm \text { SD) }\end{array}$ & $\begin{array}{c}\text { Range of } \\
\text { Maximum } \\
\text { Temperature }\left({ }^{\circ} \mathrm{C}\right)\end{array}$ & $\begin{array}{c}\text { Average } \\
\text { Relative } \\
\text { Humidity }(\%)\end{array}$ & $\begin{array}{c}\text { Highest } \\
\text { recorded value } \\
\text { of Relative } \\
\text { Humidity }(\%)\end{array}$ & $\begin{array}{c}\mathrm{HI}\left({ }^{\circ} \mathrm{C}\right) \\
(\text { mean } \pm \\
\mathrm{SD})\end{array}$ & $\begin{array}{c}\text { Highest } \\
\text { recorded } \\
\text { value of } \\
\mathrm{HI}\left({ }^{\circ} \mathrm{C}\right)\end{array}$ \\
\hline 2006 & $36.2 \pm 3.4$ & $26.7-42.0$ & $51.5 \pm 12.9$ & 85 & $44.1 \pm 5.1$ & 58.1 \\
\hline 2007 & $37.2 \pm 3.6$ & $27.0-42.5$ & $45.2 \pm 14.6$ & 85 & $43.6 \pm 5.7$ & 56.4 \\
\hline 2008 & $36.6 \pm 3.4$ & $23.2-41.9$ & $44.5 \pm 15.2$ & 95 & $41.9 \pm 3.9$ & 51.6 \\
\hline 2009 & $38.4 \pm 2.7$ & $29.4-43.4$ & $33.9 \pm 11.0$ & 64 & $41.7 \pm 4.1$ & 50.7 \\
\hline 2010 & $38.8 \pm 3.2$ & $30.1-44.5$ & $38.3 \pm 14.8$ & 81 & $44.3 \pm 4.9$ & 58.8 \\
\hline 2011 & $37.9 \pm 2.5$ & $30.0-42.1$ & $36.9 \pm 11.5$ & 63 & $42.3 \pm 5.1$ & 59.4 \\
\hline 2012 & $38.8 \pm 3.0$ & $29.1-43.1$ & $38.7 \pm 13.3$ & 81 & $44.7 \pm 5.5$ & 68.9 \\
\hline 2013 & $38.5 \pm 4.2$ & $27.0-46.0$ & $38.4 \pm 16.9$ & 80 & $43.5 \pm 5.8$ & 56.4 \\
\hline 2014 & $38.3 \pm 3.7$ & $27.0-44.0$ & $39.2 \pm 12.9$ & 82 & $43.5 \pm 5.9$ & 61.6 \\
\hline 2015 & $37.1 \pm 3.7$ & $28.8-45.0$ & $44.4 \pm 14.7$ & 84 & $43.3 \pm 6.0$ & 61.8 \\
\hline $2006-$ & $37.8 \pm 3.5$ & $23.2-46.0$ & $41.1 \pm 14.7$ & 95.0 & $43.3 \pm 5.3$ & 68.9 \\
2015 & & & & & & \\
\hline
\end{tabular}

Table-2 shows that the mean daily all-cause mortality has been estimated at $100.1 \pm 21.5$ for the study period. The minimum and maximum mean daily mortality is $79.3 \pm 10.3$ and $126.7 \pm 15.1$ for the year 2010 and
2009 respectively. The year 2013 was warmer in terms of high temperature with the maximum temperature of $\geq 40^{\circ} \mathrm{C}$ for 57 days as compared to the rest of the study period.

Table 2: Year-wise summer days, highest recorded maximum temperature and all-cause mortality from 2006 to 2015 , Hyderabad

\begin{tabular}{|c|c|c|c|c|}
\hline Year & $\begin{array}{c}\text { No. Of } \\
\text { Summer } \\
\text { Days }\end{array}$ & $\begin{array}{c}\text { No. Of Days with } \\
\text { Maximum Temperature } \\
\geq 40^{\circ} \mathrm{C}\end{array}$ & $\begin{array}{c}\text { Summer All-cause } \\
\text { Mortality } \\
\text { (Total Deaths) }\end{array}$ & $\begin{array}{c}\text { Mean All-cause } \\
\text { Mortality (per } \\
\text { day) }\end{array}$ \\
\hline 2006 & 122 & 20 & 11,606 & $95.13 \pm 13.32$ \\
\hline 2007 & 122 & 32 & 12,167 & $99.72 \pm 15.06$ \\
\hline 2008 & 122 & 32 & 11,728 & $96.13 \pm 13.98$ \\
\hline 2009 & 122 & 38 & 15,459 & $126.71 \pm 15.07$ \\
\hline 2010 & 122 & 50 & 9,670 & $79.26 \pm 10.33$ \\
\hline 2011 & 122 & 31 & 15,112 & $123.86 \pm 11.92$ \\
\hline 2012 & 122 & 46 & 14,257 & $116.86 \pm 20.18$ \\
\hline 2013 & 122 & 57 & 10,167 & $83.33 \pm 13.21$ \\
\hline 2014 & 122 & 55 & 9,986 & $81.85 \pm 10.46$ \\
\hline 2015 & 122 & 29 & 11,965 & $98.07 \pm 14.73$ \\
\hline $2006-2015$ & 1220 & 390 & 122,117 & $100.10 \pm 21.5$ \\
\hline
\end{tabular}


The mean number of deaths (both for male and female) per day at maximum temperature of less than $35^{\circ} \mathrm{C}$ was 91.11 which increased to 105.71 at daily maximum temperature of $40^{\circ} \mathrm{C}$ and above. This shows that 14.6 $(16 \%)$ mean deaths per day increased at the maximum temperature of $40^{\circ} \mathrm{C}$ and above. The mean number of deaths per day for less risky or caution days (HI: 27$31^{\circ} \mathrm{C}$ ) was 87.33 which increased to 101.96 at $\mathrm{HI}$ of more than $54^{\circ} \mathrm{C}$ (extreme danger / most risky days). This shows that there was a per day rise of $14.63(17 \%)$ mean deaths for extreme danger level days (Table-3).

Table-3: All-cause mortality (Male, Female and Total) with summer temperature and HI for the years 2006 to 2015, Hyderabad City

\begin{tabular}{|c|c|c|c|c|}
\hline Factor & Day & $\begin{array}{c}\text { Male } \\
\text { Mean deaths / } \\
\text { Day }(95 \% C I)\end{array}$ & $\begin{array}{c}\text { Female } \\
\text { Mean deaths / } \\
\text { Day (95\% CI) }\end{array}$ & $\begin{array}{c}\text { All-Cause Mortality } \\
\text { Mean deaths / } \\
\text { Day (95\% CI) }\end{array}$ \\
\hline \multicolumn{5}{|l|}{$T \operatorname{Max}\left({ }^{\circ} \mathrm{C}\right)$} \\
\hline$<35$ & 231 & $58.47(57.01-59.93)$ & $32.64(31.62-33.65)$ & $91.11(89.05-93.18)$ \\
\hline $35-39$ & 599 & $63.71(62.63-64.79)$ & $36.18(35.49-36.87)$ & 99.89 (98.34-101.44) \\
\hline$\geq 40$ & 390 & $66.50(64.84-68.16)$ & $39.21(38.11-40.31)$ & $105.71(103.18-108.24)$ \\
\hline \multicolumn{5}{|l|}{$T \operatorname{Max}\left({ }^{\circ} \mathrm{C}\right)$} \\
\hline$<45$ & 1216 & $63.58(62.77-64.39)$ & $36.47(35.93-37.01)$ & $100.06(98.85-101.26)$ \\
\hline$\geq 45$ & 4 & $72.25(48.49-96.00)$ & $38.75(23.85-53.64)$ & $111.00(74.55-147.44)$ \\
\hline \multicolumn{5}{|c|}{ Heat Index $\left({ }^{\circ} \mathrm{C}\right)$} \\
\hline $27-32$ & 15 & $55.00(45.41-64.58)$ & $32.33(26.39-38.26)$ & 87.33 (72.88- 101.77) \\
\hline $32-41$ & 397 & $62.97(61.62-64.33)$ & $35.37(34.48-36.26)$ & $98.35(96.38-100.32)$ \\
\hline $41-54$ & 774 & $64.04(63.00-65.07)$ & $37.11(36.41-37.80)$ & $101.15(99.59-102.71)$ \\
\hline$>54$ & 33 & $65.06(59.76-70.35)$ & $36.90(33.41-40.40)$ & $101.96(94.61-109.32)$ \\
\hline
\end{tabular}

Table-4 depicts that the mean daily mortality shows a significant association with daily maximum temperature $(\mathrm{P}<0.001)$ and $\mathrm{HI}$ or discomfort index from caution to danger risk days $(\mathrm{P}<0.0183)$.

The lag effect of extreme heat on all-cause mortality for the study period (2006 to 2015) was at peak period on same day of the maximum temperature $(r=0.273$ at $\mathrm{p}<0.01)$ but continues in decreasing order for next four days. While the lag effect of average temperature was high on same day $(\mathrm{r}=0.228$ at $\mathrm{p}<0.01)$ but for minimum temperature it was increasing for next two days ( $\mathrm{r}$ $=0.134$ at $\mathrm{p}<0.01)($ Table-5).

Table-4: Association of Temperature and HI with summer all-cause mortality for the years 2006 to 2015, Hyderabad City

\begin{tabular}{|c|c|c|c|c|}
\hline Variable & Categories & $\mathrm{n}=1220$ & $\begin{array}{c}\text { Mean deaths per } \\
\text { day }\end{array}$ & t-test / F Test \\
\hline $\begin{array}{l}\text { Temperature } \\
\text { (Average) })^{\circ} \mathrm{C}\end{array}$ & $\begin{array}{l}35-39 \\
<35\end{array}$ & $\begin{array}{c}115 \\
1105 \\
\end{array}$ & $\begin{array}{c}110.40 \\
99.02 \\
\end{array}$ & $\begin{array}{c}5.46 \\
(p<0.001) \\
\end{array}$ \\
\hline $\begin{array}{l}\text { Temperature } \\
\text { (Maximum) }^{\circ} \mathrm{C}\end{array}$ & $\begin{array}{l}<35 \\
35-39 \\
\geq 40\end{array}$ & $\begin{array}{l}231 \\
599 \\
390\end{array}$ & $\begin{array}{c}91.11 \\
99.89 \\
105.71\end{array}$ & $\begin{array}{l}F=35.41 \\
(p<0.000)\end{array}$ \\
\hline Heat Index ${ }^{\circ} \mathrm{C}$ & $\begin{array}{l}27-32 \\
32-41 \\
41-54 \\
>54\end{array}$ & $\begin{array}{c}15 \\
397 \\
774 \\
33\end{array}$ & $\begin{array}{c}87.33 \\
98.35 \\
101.15 \\
101.96\end{array}$ & $\begin{array}{c}F=3.35 \\
(p<0.0183)\end{array}$ \\
\hline
\end{tabular}


Table-5: Lag time correlation of temperature and humidity with all-cause mortality counts (2006 to 2015), Hyderabad city

\begin{tabular}{lllllll}
\hline Pearson Correlation Coefficient & No lag & 1 day & 2 days & 3 days & 4 days \\
\hline \hline Average Temp $\left({ }^{\circ} \mathrm{C}\right)$ & & & & & \\
Maximum Temp $\left({ }^{\circ} \mathrm{C}\right)$ & $0.228^{* *}$ & $0.209^{* *}$ & $0.200^{* *}$ & $0.181^{* *}$ & $0.185^{* *}$ \\
Minimum Temp $\left({ }^{\circ} \mathrm{C}\right)$ & $0.273^{* *}$ & $0.266^{* *}$ & $0.259^{* *}$ & $0.241^{* *}$ & $0.226^{* *}$ \\
Humidity $(\%)$ & $0.127^{* *}$ & $0.131^{* *}$ & $0.134^{* *}$ & $0.121^{* *}$ & $0.117^{* *}$ \\
$\mathrm{HI}\left({ }^{\circ} \mathrm{C}\right)$ & $-0.292^{* *}$ & $-0.274^{* *}$ & $-0.262^{* *}$ & $-0.245^{* *}$ & $-0.236^{* *}$ \\
& $0.071^{*}$ & $0.079^{* *}$ & $0.090^{* *}$ & $0.085^{* *}$ & $0.077^{* *}$
\end{tabular}

${ }^{*} \mathrm{p}<0.05 ; * * \mathrm{p}<0.01$

\section{Discussion}

Since 2010 onwards, heat waves in South Asia have been increasing especially in India ${ }^{5}$. These heat waves have caught the attention of the public health experts, policy makers, and climatologists who wish to develop the early warning system, heat action plans and increase community awareness to improve preventive measures for heat waves ${ }^{21}$. Due to climate change, extreme heat days are increasing which may lead to increase in all-cause mortality ${ }^{22}$. High temperature, especially along side humidity may be a matter of concern for many of the cities / urban areas in reference to heat morbidity and mortality. This study investigated the association of daily maximum temperature, daily minimum temperature, humidity and Heat index with all-cause mortality in $\mathrm{Hy}$ derabad City. There is an observed association between heat, heat index and all-cause mortality for Hyderabad city. Although similar heat-mortality studies have been conducted in western countries and some studies are available from Southeast Asia including India, 5,6,7,8,9,10 but to the best of our knowledge, there are no studies available on the urban population of Hyderabad city. There is a significant rise in the all-cause mortality risk with rise of maximum temperature consistent with other studies $23,24,25,26,27$. Findings also show that moderate increase in maximum temperature may lead to large rises of all-cause mortality, a consistent with study by Mazdiyasni O, et.al. ${ }^{28}$. Further, the findings substantiate that maximum temperatures between $35-39^{\circ} \mathrm{C}$ contributed to higher attributable risks of all-cause mortality than $<35^{\circ} \mathrm{C}$ and $\geq 40^{\circ} \mathrm{C}$ maximum temperatures in India during 2006-2015, consistent with previous findings ${ }^{29}$. We document a substantially greater number of deaths attributable to moderately hot temperature than to extremely hot temperatures. This is partly due to the high- er proportion of moderately hot days than extremely hot during the study period.

Although the 2011 and 2015 had less number of days with temperature equal to or more than $40^{\circ} \mathrm{C}$ but mean daily deaths were higher for the year 2011 and almost similar for the year 2015 with reference to mean allcause mortality for the entire study period. This can be explained by the fact that temperature may be more high for those summer days which can result high allcause mortality.

The high heat index values seem to be well correlated with the all-cause mortality, this confirms Desai et al., and Monteiro et al. results ${ }^{5,30}$. Maximum temperature as well as heat index are correlated with increase in allcause mortality as evident from this analysis by increase of $16 \%$ deaths/day and $17 \%$ deaths/day. Hence, there is a need for the inclusion of humidity measures while calculating all-cause mortality impacts of ambient heat. The present analysis reveals that there were 390 out of 1,220 summer days having temperature $\geq 40^{\circ} \mathrm{C}$ and 807 out of 1,220 summer days having feel temperature / heat index $\geq 41{ }^{\circ} \mathrm{C}$. Both these are critical not just for increased all-cause mortality but also work performance of the population which may have an impact on the economy of Hyderabad, and personal health that may lead to dangerous heat disorders like muscle cramps, heat strokes ${ }^{31}$. These findings support the efforts of National Disaster Management Authority ${ }^{32}$ and various Non-governmental organizations to build up the resilience of these vulnerable populations to more severe heat waves. Hence, the authorities in Hyderabad needs to plan and implement interventions to such adverse climatic heat affects. 


\section{Limitations}

Few limitations of this analysis must be acknowledged. 1. Due to unavailability of data on age or cause of death, all-cause mortality data were analyzed as done previously ${ }^{9,33}$.

2. This analysis was unable to isolate the heat related mortality due to unavailability of cause specific deaths. Hence we used all-cause mortality as an outcome variable and our estimate may be an overestimate or underestimate of the true effect of the heat and humidity on mortality.

3. Since retrospective data were used, its accuracy and completeness could not be fully verified.

\section{Conclusion}

A total of 122,117 deaths (all-cause mortality) for 1,220 summer days (2006-2015) were analyzed in reference to temperature and relative humidity. The study concludes that the maximum temperature of $\geq 40^{\circ} \mathrm{C}$ and $\mathrm{HI}>41^{\circ} \mathrm{C}$ are the important predictors for all-cause mortality of urban population of Hyderabad. The mean daily allcause mortality has been estimated at $100.1 \pm 21.5$ for the study period. There is an increase of $16 \%$ per day all-cause mortality at the maximum temperature of $40^{\circ} \mathrm{C}$ and above. Almost similar rise of $17 \%$ per day all-cause mortality for extreme danger days $\left(\mathrm{HI}>54^{\circ} \mathrm{C}\right)$. Mean daily all-cause mortality demonstrates an significant association with daily maximum temperature and HI. The effect of extreme heat on all-cause mortality for the study period (2006 to 2015) was at a peak on same day of the maximum temperature. Maximum temperature should be given more importance than average and minimum temperature while calculating the lag effect. Our findings contribute to a better understanding of local heat wave and hot days which can support the design for local thermal comfort standards and early warning systems for heat wave. Extreme heat related mortality merits further analysis in order to reduce harmful health effects among Hyderabad's most vulnerable population.

\section{Recommendations}

The findings from this study demonstrate the need for preventive actions to protect the population from the effects of temperature at city level. While the Telangana government has developed a state heat action plan we believe that specific plans for urban populations be developed. Therefore Hyderabad city should develop a specific heat action plan. Further research can be directed on heat wave with age and cause-specific mortality. We also recommend that heat index should be consid- ered while calculating all-cause mortality due to extreme heat.

\section{Acknowledgment}

Authors would like to acknowledge the support provided by Dr. SD Gupta, and Dr. Arindam Das. We would like to thank Dr. Nanditha Chauhan for helping in acquiring the all-cause mortality data. We are grateful to Mr. Hira Pant for assisting in data analysis.

\section{Conflict of interest}

The authors declare that they have no conflict of interests.

\section{Funding Sources}

This is a PHD thesis research data (IIHMR University, India) and did not receive any specific grant from funding agencies in the public, commercial, or not-for-profit sectors.

\section{Author's Statement for Contribution}

Suresh K Rathi: Conceptualization, Methodology, Data curation, Analysis, Original draft preparation

P R Sodani: Conceptualization, Methodology, Supervision, Reviewing and Editing

\section{References}

1. WMO 2017. Statement on the State of the Global Climate in 2016 (Geneva: World Meteorological Organization). https://library.wmo.int/doc_num.php?explnum_id=4453\#: :text=Globa $\quad 1 \% 20$ mean $\% 20$ temperatures $\% 20$ in $\% 202017$,by $\% 20$ an $\% 20 \mathrm{El} \% 20$ $\mathrm{Ni} \% \mathrm{C} 3 \% \mathrm{~B} 10 \% 20 \mathrm{ev} \quad$ ent.

2. Sanchez-Lugo A, Morice C and Berrisford P. Surface temperature State of the climate in 2015. Bulletin of the American Meteorological Society 2016; ed. J Blundten and DS Arndt pp S12-6. https://www.ametsoc.net/ sotc/StateoftheClimate2015_lowres.pdf

3. WHO (2015). Operational Framework for Building Climate Resilient Health Systems. https://apps.who. int/iris/bitstream/handle/10665/189951/978924156 5073_eng.pdf

4. Hayes K, Blashki G, Wiseman J, Burke S, Reifels L. Climate change and mental health: risks, impacts and priority actions. Int J Ment Health Syst. (2018);12:28 https://doi.org/10.1186/s13033-018-0210-6

5. Desai VK, Wagle S, Rathi SK, Patel U, Desai HS, Khatri K. Effect of ambient heat on all cause mortality in Surat City. Curr. Sci. 2015;109:1680-6. http://www. currentscience.ac.in/Volumes/109/09/1680.pdf

6. Anderson, G. B. and Bell, M. L. Heat waves in the 
United States: mortality risk during heat waves and effect modification by heat wave characteristics in 43 US communities. Environ. Health Perspect., 2011; 119: 210 218. https://www.ncbi.nlm.nih.gov/pmc/articles/ PMC3040608/

7. Vandentorren S, Suzan F, Medina S, Pascal M, Maulpoix A, Cohen J, et.al. Mortality in 13 French cities during the August 2003 heat wave. Am. J. Public Health, 2004; 94: 1518.

https://www.ncbi.nlm.nih.gov/pmc/articles / PMC1448485/pdf/0941518.pdf

8. Knowlton K, Rotkin-Ellman M, King G, Margolis HG, Smith D, Solomon G, et al. The 2006 California heat wave: impacts on hospitalizations and emergency department visits. Environ. Health Perspect., 2009; 117: 61. https://www.ncbi.nlm.nih.gov/pmc/articles/ PMC2627866/pdf/EHP-117- 61.pdf

9. Azhar GS, Mavalankar D, Nori-Sarma A, Rajiva1 A, Dutta P, Jaiswal A, et al., Heat-related mortality in India: excess all- cause mortality associated with the 2010 Ahmedabad heat wave. PLoS One, 2014; 9(3): e91831; doi: 10.1371/journal.pone. 0091831. https://journals. plos.org/plosone / article $/$ file?id=10.1371 / journal. pone.0091831\&type $=$ printable

10. De US, Mukhopadhyay RK. Severe heatwave over the Indian subcontinent in 1998, in perspective of global climate change. Curr. Sci., 1998; 75: 1308-1311. https://www.currentscience.ac.in/Downloads/article_ id_075_12_1308_1311_0.pdf

11. Desai VK, Patel U, Rathi SK, Wagle S, Desai HS. Temperature and Humidity Variability for Surat (coastal) city, India. International Journal of Environmental Sciences. 2015; 5(5):935-46. doi: 10.6088/ijes.2014050100088. http:/ /www.ipublishing.co.in/ijesarticles/fourteen/articles/volfi ve/EIJES51088.pdf

12. Ratnam J V, Behera S K, Ratna S B, Rajeevan M and Yamagata T. Anatomy of Indian heatwaves. Sci. Rep. 2016; 6: 24395. https://www.ncbi.nlm.nih.gov/pmc/ articles/PMC4832141/pdf/srep2439 5.pdf

13. Im E-S, Pal JS, Eltahir EAB. Deadly heat waves projected in the densely populated agricultural regions of South Asia. Sci. Adv. 2017; 3: e1603322. https:// www.ncbi.nlm.nih.gov/pmc/articles/PMC5540239/ pdf/1603322. pdf

14. Luke JH, David JF, Erich MF, Ed H, Manoj J, Chris D J. Poorest countries experience earlier anthropogenic emergence of daily temperature extremes. Environ. Res. Lett. 2016;11: 055007

15. https://www.thehansindia.com/telangana/10-heatstroke-cases-across-hyderabad-everyday-530817 16.https://www.deccanherald.com/national/south/ heat-wave-kills-111-in-ap-telangana-in-42-days-733180. html

17. http://www.tutiempo.net/en/Climate/.html

18. Rothfusz L.P. The heat index equation. Technical attachment, Scientific Services Division NWS Southern Region Headquarters, Fort Worth, TX, SR 90-23, 1990. https://www.weather.gov/media/ffc/ta_htindx.PDF

19. Rajib MA, Mortuza MR, Selmi S, Asif Khan Ankur AK, Rahman MM. Increase of heat index over Bangladesh: impact of climate change. World Academy of Science, Engineering and Technology 2011; 5(10): 340-343.https:// publications.waset.org/14026/increase-of-heat-indexover- bangladesh-impact-of-climate-change

20. Zahid M, Rasul G. Rise in summer heat index over Pakistan. Pakistan Journal of Meteorology. 2010; 6(12): 8596.

21. Nissan H, Burkart K, Coughlan de Perez E, van Aalst M, Mason S. Defining and predicting heat waves in Bangladesh.J. Appl. Meteorol. Climatol. 2017; 56:2653-70. https://doi.org/10.1175/JAMC-D-17-0035.1.https:// journals.ametsoc.org/jamc/article/56/10/2653/20335 22. Agarwal AK, Dwivedi S, Ahirwar G. A study of consistent health impact by summer heat on morbidity and mortality. Int J Env Health Eng, 2018; 7(1): 1-7. DOI: 10.4103/ijehe.ijehe_8_17

23. Son JY, Lee JT, Anderson GB, Bell ML. The Impact of Heat Waves on Mortality in Seven Major Cities in Korea. Environ. Health Perspect. 2012; 120: 566-571.https:// www.ncbi.nlm.nih.gov/pmc/articles/PMC3339449/ pdf/ehp.1103 759.pdf

24. Harlan SL, Chowell G, Yang S, Petitti DB, Butler EJM, Rudell BL, et al. Heat-Related Deaths in Hot Cities: Estimates of Human Tolerance to High Temperature Thresholds. Int. J. Environ. Res. Public Health. 2014; 11: 3304-3326. https://www.ncbi.nlm.nih.gov/pmc/ articles/PMC3987036/pdf/ijerph-1 1-03304.pdf

25. Rathi SK, Desai VK, Jariwala P, Desai H, Naik A, Joseph A. Summer temperature and spatial variability of all-cause mortality in Surat city, India. Indian J Community Med. 2017;42:111-5. http://www.ijcm.org.in/ article. asp?issn $=0970-0218$; year $=2017$; volume $=42$;iss ue $=2$; spage $=111$; epage $=115$; aulast $=$ Rathi

26.Rocklov J, Forsberg B, Ebi K, Bellander T. Susceptibility to mortality related to temperature and heat and cold wave duration in the population of Stockholm County, Sweden: Globe Health Action. 2014,7: $22737-$ http://dx.doi.org/10.3402/gha.v7.22737. https:// www.tandfonline.com/doi/pdf/10.3402/gha.v7.22737 27. Singh T, Siderius C, Velde YP. When do Indians feel 
hot? Internet searches indicate seasonality suppresses adaptation to heat. Environ. Res. Lett. 2018; 13054009. https://doi.org/10.1088/1748-9326/aaba82

28. Mazdiyasni O, AghaKouchak A, Davis SJ, Madagar S, Mehran A, Ragno E, et al. Increasing probability of mortality during Indian heat waves. Sci. Adv., 2017; 3: 1-5. DOI: $10.1126 /$ sciadv. 1700066

29. Fu SH, Gasparrini A, Rodriguez PS, Jha P. Mortality attributable to hot and cold ambient temperatures in India: a nationally representative case-crossover study. PLoS Med, 2018; 15(7): 1-17. https://doi.org/10.1371/ journal.

30.Monteiro A, Carvalho V, Velho S, Sousa C. The accuracy of the heat index to explain the excess of mor- tality and morbidity during heat waves - a case study in a Mediterranean climate. Bulletin of Geography. Socio-economic Series 2013; 20: 71-84. https://apcz.umk. $\mathrm{pl} /$ czasopisma/index.php/BGSS/article/viewFile/bo g-2013-0012/821

31.https://www.aninews.in/news/national/general-news/ soaring-temperatures-lead-to-10-to-15-heatstroke-cases-per-day-in-hyderabad20190521182603/

32.https://ndma.gov.in/Natural-Hazards/Heat-Wave/ Dos-Donts

33. Pattenden S, Nikiforov B, Armstrong BG. Mortality and temperature in Sofia and London. J. Epidemiol. Community Health, 2003; 57: 628-633. https://jech.bmj. com/content/jech/57/8/628.full.pdf 